\title{
Erratum to: A novel GRAS protein gene MtSymSCL1 plays a role in regulating nodule number in Medicago truncatula
}

\author{
Goon-Bo Kim • Young-Woo Nam
}

Published online: 2 August 2013

(C) Springer Science+Business Media Dordrecht 2013

\section{Erratum to: Plant Growth Regul}

DOI 10.1007/s10725-013-9814-7

Unfortunately, the accepted date has been published incorrectly in the original publication of the article. The correct accepted date of the article is April 12, 2013.

The online version of the original article can be found under doi:10.1007/s10725-013-9814-7.

G.-B. Kim · Y.-W. Nam ( $\bowtie)$

Department of Life Science, Sogang University, Seoul 121-742,

Korea

e-mail: ywnam@sogang.ac.kr 